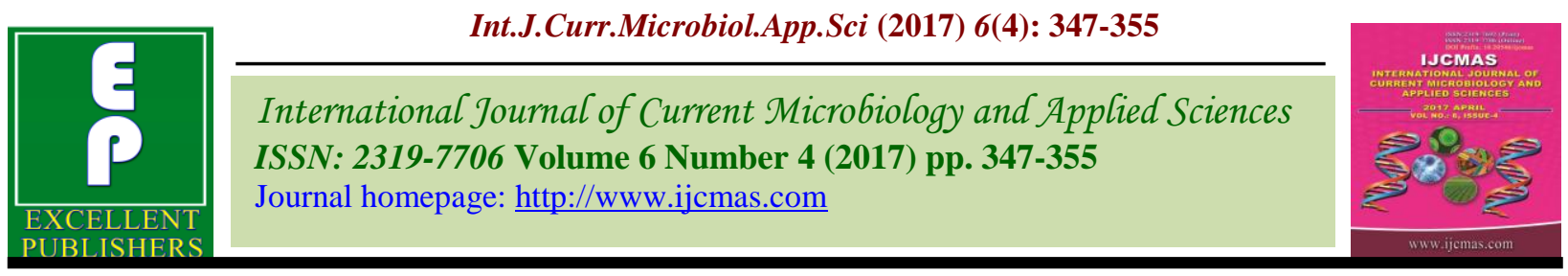

Original Research Article

https://doi.org/10.20546/ijcmas.2017.604.038

\title{
Phasic Pattern of Dry Matter Production and Accumulation in Different Parts of Cowpea Cultivars (Vigna unguiculata L. walp.) During Growth and Development Stages under Varied Seasons
}

\author{
D.V. Singh ${ }^{1}$ and S.K. Mukhi ${ }^{2}$ \\ ${ }^{1}$ Senior Scientist and Head, ${ }^{2}$ Scientist, (Soil Science), KVK, Kandhamal, Orissa University of \\ Agriculture and Technology, Bhubaneswar, (Odisha), India \\ *Corresponding author
}

\section{A B S T R A C T}

A field experiment was conducted at farming system research unit of Krishi Vigyan Kendra, Kandhamal as a part of ongoing effort to collect the data in connection to dry

\section{Keywords}

Cowpea, Dry matter accumulation, Days after sowing (DAS), Seasonal variation.

Article Info

Accepted:

02 March 2017

Available Online:

10 April 2017 matter accumulation and partitioning in three cultivars of cow pea during growth and development stages in two consecutive summer and Kharif season of the year 2012-13 and 2013-14. The dry matter partitioning had been worked out at 30, 45 and 60 DAS from the stem, leaves and at only 60 DAS from the pods. Results revealed that total dry matter production was higher in the summer season as compare to the rainy season and it increased gradually with the age of the plant. The accumulation of dry matter was more in the pod as compared to leaves and stem. Among the three varieties tested, Maharani showed significant higher accretion of dry matter in the stem $\left(3.38 \mathrm{~g} \mathrm{plant}^{-1}\right)$ as compared to Lafa (3.28 $\mathrm{g} \mathrm{plant}^{-1}$ ) and Utkal Manika (3.13 $\mathrm{g}$ plant $^{-1}$ ) during summer season. In the rainy season Lafa (1.98 $\left.\mathrm{g}_{\text {plant }}{ }^{-1}\right)$ yielded highest followed by Maharani (1.09 $\left.\mathrm{g} \mathrm{plant}^{-1}\right)$ and Utkal Manika ( $0.99 \mathrm{~g}$ plant $\left.{ }^{-1}\right)$. Varieties showed the similar trends in the accrual of the dry matter in the leaves and pods, but the amount varies. Maharani accumulate highest during summer season in both leaves and pods $4.60 \mathrm{~g} \mathrm{plant}^{-1}$ and $25.26 \mathrm{~g} \mathrm{plant}^{-1}$ respectively and lafa performed better in rainy season where accrual of dry matter was $3.01 \mathrm{~g} \mathrm{plant}^{-1}$ in the leaves and $19.81 \mathrm{~g} \mathrm{plant}^{-1}$ on the pods.

\section{Introduction}

Cowpea [Vigna unguiculata (L).Walp] is the crop of all round utilization, grown for tender pods and seeds, dry seeds as pulses, green leaves and even roots. The immature pods and seeds as well as dry seeds besides being used as fresh vegetable and pulse are also frozen and canned. It is one of the excellent legume forage and green manure crops. It valued in different countries for its varied uses. It is the key dietary staple for the poorest section of many under developed and developing countries of Africa, Latin America and Asia.
Cowpea is a food grain legume and important source of proteins, vitamins and minerals for the predominantly vegetarian population and is popularly known as "Poor man's meat" and "richman's vegetable" (Singh and Singh, 1992).

As a forage crop, it is quick growing, high yielding, with substantially rich biomass production, grows well with associated crops and is highly proteinaceous. It is mainly grown as mixed/intercrop with cereals for 
fodder production. Both the grain and the haulm are valuable dietary proteins for the population and their livestock (Fatokun, 2002). The grain contains between 20-25 percent of protein (Bressani, 1985), about twice the protein content of most cereals (Kay, 1979). It forms a major component of the tropical farming system because of its ability to improve marginal lands through nitrogen fixation and as a cover crop (Sanginga et al., 2003; Abayomi, 2008).

The crop can fix about $240 \mathrm{~kg} \mathrm{ha}^{-1}$ of atmospheric nitrogen and make available about $60-70 \mathrm{~kg}$ ha nitrogen for succeeding crops grown in rotation with it (CRI, 2006, cited by Aikins and Afuakwa, 2008). Cowpea cover crops have also been shown to suppress nematode in tomato production system by Roberts et al., (2005).

Cowpea can also be grown as catch crop or mulch crop. Incorporation of cowpea as a legume in crop sequences enriches soil fertility and provides a dense soil cover to check wind erosion and evapo-transpiration loss of soil water.

There are various problems pertaining for optimum utilization of the growing season in the coastal ecosystem of Odisha. Hence, efforts have been made to find out the effect of seasonal variation on the production of three popularly grown cowpea varieties through calculating dry matter accumulation and partitioning at different developmental growth stages. Such information would provide an understanding of the growth and development of the crop throughout the growing period.

\section{Materials and Methods}

The experiment was conducted at the farming system research unit of Krishi Vigyan Kendra, Kandhamal (Odisha) during summer
(February to May) and Kharif (June to September) season of the two consecutive years 2012-13 and 2013-14.

The rainfall pattern of the experimental site comprised 223 to $304 \mathrm{~mm}$ rainfall during February to May along with the monthly average temperature lies between 24 to $28^{0} \mathrm{C}$ for the both experimental year respectively. Maximum rainfall achieved during the Kharif season with the total rainfall ranged between $1077-1310 \mathrm{~mm}$ and the mean monthly temperature was $34^{0} \mathrm{C}$.

The soil of the experimental site was sandy loam. Soil was slightly acidic (pH-6.21), low in organic carbon status $(0.17 \%)$, low in available nitrogen $\left(40.35 \mathrm{~kg} \mathrm{ha}^{-1}\right)$, high in available phosphorus (97.03 $\mathrm{kg} / \mathrm{ha})$ and medium in available potassium $\left(203.61 \mathrm{~kg} \mathrm{ha}^{-1}\right)$.

\section{Planting materials}

Three popular varieties of cowpea suitable for coastal Odisha condition were selected for the experiment (Table 1).

The seeds of the above mentioned varieties were planted with in $10^{\text {th }}-15^{\text {th }}$ February and $15^{\text {th }}-20^{\text {th }}$ June for summer and kharif season respectively for the two consecutive experimental years, at the spacing $30 \times 10 \mathrm{~cm}$ and all the others recommended agronomic practices were followed. The plot measured $3 \mathrm{~m} \times 3 \mathrm{~m}$, design was RBD and seven replication followed.

\section{Data collection}

The growth of the crop was analysed over a period. Five plants from each plot were carefully uprooted randomly and the roots were carefully cut. Plants from each plot were placed in polythene bags and tied. Samples from the 21 plots were sent to the laboratory for growth analysis. Fresh weight for each plot sample were taken and recorded after 
partitioning of whole plant into leaf, stem and reproductive parts. After that, dry weight was taken after oven dry at $70^{\circ} \mathrm{C}$ to a constant weight. The sum of mean dry weight of all the plant parts represents total dry matter per plant $(\mathrm{g})$. The respective mean dry weight of plant parts represents dry matter accumulation in leaf, stem and pods per plant $(\mathrm{g})$. There were five samplings taken at different stages of crop growth i.e. 30, 45 and 60 DAS.

\section{Results and Discussion}

The result of total dry matter production in the stem presented in table 2 showed that dry matter production was maximum in summer compared to rainy season for both the experimental year 2012-13 and 2013-14. There was a gradual increase in the dry matter accumulation in the stem starting from the 30 DAS up to harvest.

In the year 2012-13, during summer lowest dry matter accumulated by Utkal Manika (2.88 $\left.\mathrm{g} \mathrm{plant}^{-1}\right)$ at 30 DAS which was statistically at par with the other two test varieties Lafa (2.89 $\left.\mathrm{g} \mathrm{plant}^{-1}\right)$ and Maharani (2.91g plant $\left.^{-1}\right)$. At 45 DAS total dry matter production was found to be higher in Maharani (3.19g plant $\left.^{-1}\right)$ which was significantly higher than the other two i.e. Lafa (3.07 g plant $^{-1}$ ) and Utkal Manika (3.02 g plant $^{-1}$ ) (Table 2). So also, at 60 DAS lowest dry matter assembled by the variety Utkal Manika (3.27 g plant ${ }^{-1}$ ) followed by Lafa (3.31 g plant $^{-1}$ ) and their differences were not statistically significant but differ significantly with Maharani which produced (3.47 g plant $^{-1}$ ) dry matter on the stem only.

Total dry matter accumulation in the stem followed a similar pattern for both the year. In 2011-12 at 30 DAS highest accretion of the same was recorded in Maharani (2.78 g plant $^{-1}$ ) which was significantly higher than the other two i.e. lafa (2.59 $\left.\mathrm{g} \mathrm{plant}^{-1}\right)$ and Utkal Manika
(2.49 $\left.\mathrm{g} \mathrm{plant}^{-1}\right)$. At 45 DAS Utkal Manika (2.74 $\mathrm{g} \mathrm{plant}^{-1}$ ) and Maharani (2.85 $\mathrm{g} \mathrm{plant}^{-1}$ ) showed no significant differences in the accumulation of dry matter among them but differ significantly with Lafa (2.96 g plant $^{-1}$ ). Lowest accrual of dry matter was noticed in Utkal Manika (2.98 $\left.\mathrm{g} \mathrm{plant}^{-1}\right)$ at $60 \mathrm{DAS}$ which differ significantly from the immediate follower lafa (3.25g plant $^{-1}$ ) and Maharani (3.28 $\mathrm{g} \mathrm{plant}^{-1}$ ) but the later two are statistically at par table 2 .

Two years pooled mean showed that at 30 DAS Maharani (2.85 g plant $\left.^{-1}\right)$ showed significant differences in the accumulation of the dry matter than the other two lafa $(2.74 \mathrm{~g}$ plant ${ }^{-1}$ ) and Utkal Manika (2.69 $\mathrm{g} \mathrm{plant}^{-1}$ ) which had statistical parity. At 45 DAS no significant difference was found among the three varieties tested viz. Utkal Manika (2.88 g plant $\left.{ }^{-1}\right)$, Maharani (3.02 g plant $\left.^{-1}\right)$ and Lafa (3.10 $\left.\mathrm{g} \mathrm{plant}^{-1}\right)$. The dry matter produced by Utkal Manika (3.13 g plant $^{-1}$ ) at 60 DAS was found significantly different from Lafa (3.28 $\mathrm{g} \mathrm{plant}^{-1}$ ) and Maharani (3.38 g plant $\left.^{-1}\right)$ (Table 2).

During rainy season of the year 2012-13, dry matter accumulation was highest in the stem of Lafa (1.71 $\left.\mathrm{g} \mathrm{plant}^{-1}\right)$ after 30 DAS followed by Maharani $\left(0.87 \mathrm{~g}\right.$ plant $\left.^{-1}\right)$ and their differences were statistically significant. Lowest accrual of dry matter was found in Utakl Manika (0.81 $\left.\mathrm{g} \mathrm{plant}^{-1}\right)$ that did not show any significant difference from Maharani but was highly significant from Lafa. After 45 DAS lowest dry matter was produced by Utkal Manika (0.86 g plant $\left.^{-1}\right)$ followed by Maharani $\left(0.99 \mathrm{~g}\right.$ plant $\left.{ }^{-1}\right)$ and their differences was statistically significant. Highest productions of the same by Lafa (1.86 $\mathrm{g} \mathrm{plant}^{-1}$ ) also differ significantly from the other two. Similarly at 60 DAS varietal differences in accumulation of dry matter were highly significant. Lafa recorded the highest (1.92 $\mathrm{g} \mathrm{plant}^{-1}$ ) followed by Maharani 
$\left(1.06 \mathrm{~g} \mathrm{plant}^{-1}\right)$ and Utkal Manika (0.89 $\mathrm{g}$ plant $^{-1}$ ) (Table 2).

In the year 2013-14 at 30 DAS Lafa showed significant differences in the production of dry matter $\left(1.58 \mathrm{~g} \mathrm{plant}^{-1}\right)$ from the other two varieties Maharani $\left(0.78 \mathrm{~g}_{\text {plant }}{ }^{-1}\right)$ and Utkal Manika (0.76 g plant $\left.{ }^{-1}\right)$ but the later two was statistically at par. At 45 DAS all the three varieties showed significant differences among them in the accumulation of dry matter i.e. highest production by Lafa (1.95 $\left.\mathrm{g} \mathrm{plant}^{-1}\right)$ followed by Maharani (0.96 g plant $\left.{ }^{-1}\right)$ and Utkal Manika (0.83 g plant $\left.{ }^{-1}\right)$. Unlike 45 DAS, the accretion of dry matter at 60 DAS showed statistical parity between the varieties Utkal Manika (1.09 $\left.\mathrm{g} \mathrm{plant}^{-1}\right)$ and Maharani (1.12g plant $\left.{ }^{-1}\right)$ but Lafa which produce $(2.03 \mathrm{~g}$ plant $\left.^{-1}\right)$ differ significantly from the other two (Table 2).

The two years pooled mean showed no significant difference among Utkal Manika (0.86 g plant $^{-1}$ ) and Maharani (0.99 g plant $\left.^{-1}\right)$ but differ significantly from Lafa $(1.86 \mathrm{~g}$ plant $^{-1}$ ) at 30 DAS. Highest accumulation of dry matter at 45 DAS was observed in Lafa $\left(1.91 \mathrm{~g} \mathrm{plant}^{-1}\right)$ followed by Maharani $(0.98 \mathrm{~g}$ plant $\left.^{-1}\right)$ and Utkal Manika (0.85 $\left.\mathrm{g} \mathrm{plant}^{-1}\right)$ and their differences were statistically different. The accrual of dry matter at 60 DAS showed no significant differences among Utkal Manika (0.99 $\left.\mathrm{g} \mathrm{plant}^{-1}\right)$ and Maharani (1.09 g plant $^{-1}$ ) but differ significantly from Lafa (1.98 $\mathrm{g} \mathrm{plant}^{-1}$ ) (Table 2). Haizel (1972) and Turk et al., (1980), also found that cowpea varieties have different capacities for dry matter accumulation. The dry matter accumulation in leaves was significantly influenced by growing season at all the growth stages.

In 2012-13, during summer season Maharani recorded significantly higher dry matter accumulation in leaves at 30 DAS $(1.90 \mathrm{~g}$ plant $\left.^{-1}\right)$ compared to lafa $\left(1.78\right.$ g plant $\left.^{-1}\right)$ and Utkal Manika (1.69g plant $\left.{ }^{-1}\right)$ but the differences between the later two was statistically at par. Similar trend was observed at 45 and 60 DAS where accumulation of dry matter was found highest in Maharani (4.19 g plant $^{-1}$ and 4.51 g plant $^{-1}$ respectively) which differ significantly from the other two varieties like lafa $\left(3.47 \mathrm{~g} \mathrm{plant}^{-1}\right.$ and $4.47 \mathrm{~g}$ plant $^{-1}$ in that order) and Utkal Manika (3.30 g plant $^{-1}$ and $4.17 \mathrm{~g} \mathrm{plant}^{-1}$ individually) through the later two varieties show no significant differences among them (Table 3).

The dry matter accumulation in leaves at 30 DAS in the year 2011-12 was found nonsignificant between the lowest produced variety Utkal Manika (1.49 $\left.\mathrm{g} \mathrm{plant}^{-1}\right)$ and its immediate follower lafa $\left(1.65 \mathrm{~g}\right.$ plant $\left.^{-1}\right)$ but differ significantly Maharani which produced the highest $\left(1.93 \mathrm{~g} \mathrm{plant}{ }^{-1}\right)$. At 45 DAS accretion of dry matter in the leaves was highest in lafa $\left(3.97 \mathrm{~g}\right.$ plant $\left.^{-1}\right)$ which differ significantly from Maharani (3.66g plant ${ }^{-1}$ ) and Utkal Manika (3.29g plant ${ }^{-1}$ ) but the differences between Maharani and Utkal Manika was statistically at par. Unlike 30 and 45 DAS, the production of dry matter in the leaves differed significantly among the three varieties at 60 DAS during summer season. Maharani which yielded higher (4.68 g plant $\left.{ }^{-1}\right)$ followed by lafa $\left(4.45 \mathrm{~g} \mathrm{plant}^{-1}\right)$ and Utkal Manika (3.98 $\mathrm{g} \mathrm{plant}^{-1}$ ) and their differences were statistically significant (Table 3 ).

Two years pooled data showed that there were no significant differences among the lowest produced Utkal Manika (1.59 $\mathrm{g}_{\text {plant }}{ }^{-1}$ ) and Lafa $\left(1.72 \mathrm{~g}\right.$ plant $\left.^{-1}\right)$ at 30 DAS but differ significantly from Maharani which produced the highest $\left(1.92 \mathrm{~g} \mathrm{plant}^{-1}\right)$. At 45 DAS no significant differences were noticed in the accrual of dry matter in leaves amongst Lafa that accumulate $\left(3.72 \mathrm{~g} \mathrm{plant}^{-1}\right)$ and Maharani (3.92g plant ${ }^{-1}$ ) but the lowest producer Utkal Manika (3.30g plant ${ }^{-1}$ ) differ significantly with Maharani however statistically at par with Lafa. Unlikely, at 60 DAS the accretion of dry matter showed statistical parity 
between all the three varieties like Maharani, Lafa and Utkal Manika which yielded 4.60g plant $^{-1}, 4.46$ plant $^{-1}$ and 4.07 respectively (Table 3).

The results of total dry matter production during rainy days for both the two experimental years are presented in table 3 . In the year 2012-13, total dry matter yield in Lafa (1.81g plant $\left.^{-1}\right)$ was significantly higher than Maharani $\left(0.96 \mathrm{~g}\right.$ plant $\left.^{-1}\right)$ and Utkal Manika (0.91 $\left.\mathrm{g} \mathrm{plant}^{-1}\right)$ at 30 DAS however the later two did not show any significant differences among them. So also, at 45 DAS lowest producer Utkal Manika (1.35g plant $^{-1}$ ) showed no significant differences from Maharani (1.48g plant $\left.{ }^{-1}\right)$ but differ significantly from Lafa $\left(2.56 \mathrm{~g} \mathrm{plant}^{-1}\right)$. At 60 DAS significant differences was observed between the lowest produced Utkal Manika $\left(1.89 \mathrm{~g} \mathrm{plant}^{-1}\right)$ with the rest two varieties Maharani (2.36g plant $\left.{ }^{-1}\right)$ and lafa (2.95g plant $\left.{ }^{-1}\right)$ (Table 3).

Significant difference in the accrual of dry matter in leaves was noticed in lafa $(1.78 \mathrm{~g}$ plant $^{-1}$ ) at 30 DAS during the rainy season of the year 2013-14, as compare to the other two test varieties i.e Maharani (1.22g plant $\left.{ }^{-1}\right)$ and UtkalManika (0.86 $\left.\mathrm{g} \mathrm{plant}^{-1}\right)$ however the differences between these two varieties were statistically at par. At 45 DAS, no significant differences were found between the lowest producer was Utkal Manika $\left(2.75 \mathrm{~g}\right.$ plant $\left.^{-1}\right)$ and Maharani (1.83g plant $\left.{ }^{-1}\right)$ but differ significantly from Lafa which produced the highest $\left(1.95 \mathrm{~g} \mathrm{plant}^{-1}\right)$. Like $45 \mathrm{DAS}$, at 60 DAS non-significant differences was found between the lowest yielded variety Utkal Manika (1.93g plant $\left.{ }^{-1}\right)$ and its immediate follower Maharani (2.42 $\mathrm{g} \mathrm{plant}^{-1}$ ) but differ significantly from lafa $\left(3.08 \mathrm{~g} \mathrm{plant}^{-1}\right)$ (Table 3).

Two years pooled data showed no significant difference among Utkal Manika (0.89 g plant $^{-1}$ ) and Maharani (1.09g plant $\left.{ }^{-1}\right)$ but differ significantly from Lafa $\left(1.80 \mathrm{~g} \mathrm{plant}^{-1}\right)$ at 30 DAS. Highest accumulation of dry matter in leaves at 45 DAS was observed in Lafa $(2.66 \mathrm{~g}$ plant $^{-1}$ ) followed by Maharani (1.66g plant ${ }^{-1}$ ) and Utkal Manika (1.52g plant $\left.{ }^{-1}\right)$ and their differences were statistically significant. The production of dry matter in the leaves differed significantly among the three varieties at 60 DAS during rainy season. Lafa yielded higher (3.01 $\left.\mathrm{g} \mathrm{plant}^{-1}\right)$ followed by Maharani $(2.39 \mathrm{~g}$ plant $^{-1}$ ) and Utkal Manika (1.91g plant ${ }^{-1}$ ) and their differences were statistically significant (Table 3).

According to Kvet et al., 1971, leaves are the assimilatory apparatus of the plant, is said to be the primary factor that determines the rate of dry matter production in a closed stand. It also reflects differences in productive efficiency between crop varieties. This supports the fact that differences between the dry matter accumulations in the leaves of three different varieties growing in the different season.

The dry matter accumulation in the pod was significantly influenced by the growing season. Significantly higher accumulation of dry matter observed during summer season as compare to rainy season.

In the year 2012-13, during summer season highest accrual of dry matter observed in Maharani (25.95 $\mathrm{g} \mathrm{plant}^{-1}$ ) followed by lafa (22.65 $\mathrm{g} \mathrm{plant}^{-1}$ ) and Utkal Manika (20.50 g plant $\left.^{-1}\right)$ and their differences were statistically significant (Table 4).

So also, in 2013-14 all the three varieties showed significant differences among them in the accumulation of dry matter in the pod i.e. highest production by Maharani (24.56 g plant $\left.^{-1}\right)$ followed by lafa $\left(21.46 \mathrm{~g} \mathrm{plant}^{-1}\right)$ and Utkal Manika (19.57 g plant $^{-1}$ ) (Table 4). 
Accretion of dry matter showed significant differences between the test varieties in the two years pooled data. Significant differences was observed among lowest production by Utkal Manika (18.08 $\mathrm{g} \mathrm{plant}^{-1}$ ) followed by Lafa $\left(20.88 \mathrm{~g} \mathrm{plant}^{-1}\right)$ and Maharani $(25.26 \mathrm{~g}$ plant $^{-1}$ ) (Table 4).

In the rainy season of 2010-11 no significant difference was found in the accumulation of dry matter in pod amongst the varieties. Lafa produced the highest $\left(19.11 \mathrm{~g}\right.$ plant $\left.^{-1}\right)$ followed by Maharani (16.65 $\mathrm{g} \mathrm{plant}^{-1}$ ) and Utkal Manika (15.65 $\mathrm{g} \mathrm{plant}^{-1}$ ) (Table 4). In 2011-12, lafa accumulate highest (20.50 g plant $^{-1}$ ) dry matter which differ significantly from the other two Maharani (17.65 g plant $^{-1}$ ) and Utkal Manika (16.50 $\mathrm{g} \mathrm{plant}^{-1}$ ) but the later two was statistically at par (Table 4).

Two years pooled mean showed the similar pattern as in case of 2013-14. Here also lafa yielded significantly higher dry matter (19.81 g plant $\left.{ }^{-1}\right)$ than the other two Maharani (17.15 g plant ${ }^{-1}$ ) and Utkal Manika (16.50 g plant $^{-1}$ ) though there were no significant differences among the later two (Table 4).

From the results obtained in this study, it could be concluded that the performance of the three cowpea varieties in terms of dry matter accumulation in different parts namely stem, leaves and pod and in different growing season showed significant differences among them in both the term. Maharani found better in summer and lafa proved to be the best variety when grown in the rainy season on the basis of the accretion of dry matter and its partitioning in the different parts. Utkal Manika remained the poorest performer for both the growing season. Dry matter production showed a gradual increase with the increased in the plant age for both the growing season. Significantly higher accumulation of dry matter observed during summer season as compare to rainy season among all the three varieties. According to Blackman (1968), during the juvenile stages of the plant vigorous exponential vegetative growth occurred which in turn led to increasing light interception by the leaves resulting in increasing rate of photosynthesis and hence dry matter yield.

It is recommended that further study be carried out on detailed growth analysis of various plant parts of cowpea to ascertain how dry matter is partitioned under different growing season, and also to establish the actual relationship between them.

Table.1 Varietal description

\begin{tabular}{|c|l|l|c|c|l|}
\hline $\begin{array}{l}\text { S. } \\
\text { No. }\end{array}$ & Varieties & \multicolumn{1}{|c|}{ Source } & $\begin{array}{c}\text { Approximat } \\
\text { e duration }\end{array}$ & Type & Morphology \\
\hline 1. & $\begin{array}{l}\text { Utkal } \\
\text { Manika } \\
(\text { BCP-3) }\end{array}$ & $\begin{array}{l}\text { Orissa } \\
\text { University of } \\
\text { Agriculture and } \\
\text { Technology }\end{array}$ & 55-60 days & Bushy & $\begin{array}{l}\text { Vegetable type pods smooth, long, } \\
\text { fleshy }\end{array}$ \\
\hline 2. & Maharani & Kisan seeds & 60 days & Pole & $\begin{array}{l}\text { Vegetable type pods, thin, long, } \\
\text { fleshy }\end{array}$ \\
\hline 3. & Lafa & Kisan seeds. & 60 days & Pole & $\begin{array}{l}\text { Vegetable type pods, thin, short, } \\
\text { fleshy }\end{array}$ \\
\hline
\end{tabular}

* Responds to 50-70-50 kg N-P $\mathrm{P}_{2} \mathrm{O}_{5}-\mathrm{K}_{2} \mathrm{O} / \mathrm{ha}$ 
Table.2 Dry matter accumulation in stem $\left(\mathrm{g} \mathrm{plant}^{-1}\right)$ of three cowpea varieties at 30DAS, 45DAS and 60DAS grown at different growing season of 2012-13 and 2013-14

\begin{tabular}{|c|c|c|c|c|c|c|c|c|c|}
\hline \multirow[t]{4}{*}{ Treatment } & \multicolumn{9}{|c|}{ Growing season- summer } \\
\hline & \multicolumn{9}{|c|}{ Days of crop growth } \\
\hline & \multicolumn{3}{|c|}{$30 \mathrm{DAS}$} & \multicolumn{3}{|c|}{$45 \mathrm{DAS}$} & \multicolumn{3}{|c|}{$60 \mathrm{DAS}$} \\
\hline & $\begin{array}{c}2012- \\
13\end{array}$ & $\begin{array}{c}2013- \\
14\end{array}$ & Pooled & $\begin{array}{c}2012- \\
13\end{array}$ & $\begin{array}{c}2013- \\
14\end{array}$ & Pooled & $\begin{array}{c}2012- \\
13\end{array}$ & $\begin{array}{c}2013- \\
14\end{array}$ & $\begin{array}{c}\text { Pool } \\
\text { ed }\end{array}$ \\
\hline Maharani & 2.91 & 2.78 & 2.85 & 3.19 & 2.85 & 3.02 & 3.47 & 3.28 & 3.38 \\
\hline Lafa & 2.89 & 2.59 & 2.74 & 3.07 & 2.96 & 3.10 & 3.31 & 3.25 & 3.28 \\
\hline Utkal Manika & 2.88 & 2.49 & 2.69 & 3.02 & 2.74 & 2.88 & 3.27 & 2.98 & 3.13 \\
\hline $\operatorname{Sem}(\underline{+})$ & 0.03 & 0.04 & 0.02 & 0.03 & 0.04 & 0.06 & 0.04 & 0.03 & 0.03 \\
\hline C.D.(0.05) & 0.10 & 0.15 & 0.06 & 0.14 & 0.16 & 0.25 & 0.17 & 0.11 & 0.99 \\
\hline \multicolumn{10}{|c|}{ Growing season- Rainy } \\
\hline Maharani & 0.87 & 0.78 & 0.83 & 0.99 & 0.96 & 0.98 & 1.06 & 1.12 & 1.09 \\
\hline Lafa & 1.71 & 1.58 & 1.65 & 1.86 & 1.95 & 1.91 & 1.92 & 2.03 & 1.98 \\
\hline UtkalManika & 0.81 & 0.76 & 0.79 & 0.86 & 0.83 & 0.85 & 0.89 & 1.09 & 0.99 \\
\hline $\operatorname{Sem}(+)$ & 0.03 & 0.01 & 0.01 & 0.24 & 0.30 & 0.01 & 0.02 & 0.04 & 0.02 \\
\hline C.D. $(0.05)$ & 0.13 & 0.06 & 0.05 & 0.09 & 0.12 & 0.06 & 0.09 & 0.15 & 0.10 \\
\hline
\end{tabular}

DAS= Days after sowing

Table.3 Dry matter accumulation in leaf $\left(\mathrm{g} \mathrm{plant}^{-1}\right)$ of cowpea at 30DAS, 45DAS and 60DAS grown at different growing season of 2012-13 and 2013-14

\begin{tabular}{|c|c|c|c|c|c|c|c|c|c|}
\hline \multirow[t]{4}{*}{ Treatment } & \multicolumn{9}{|c|}{ Growing season- summer } \\
\hline & \multicolumn{9}{|c|}{ Days of crop growth } \\
\hline & \multicolumn{3}{|c|}{$30 \mathrm{DAS}$} & \multicolumn{3}{|c|}{$45 \mathrm{DAS}$} & \multicolumn{3}{|c|}{$60 \mathrm{DAS}$} \\
\hline & $\begin{array}{c}2012- \\
13\end{array}$ & $\begin{array}{c}2013- \\
14\end{array}$ & Pooled & $\begin{array}{c}2012- \\
13\end{array}$ & $\begin{array}{c}2013- \\
14\end{array}$ & Pooled & $\begin{array}{c}2012- \\
13\end{array}$ & $\begin{array}{c}2013- \\
14\end{array}$ & $\begin{array}{c}\text { Pool } \\
\text { ed }\end{array}$ \\
\hline Maharani & 1.90 & 1.93 & 1.92 & 4.19 & 3.66 & 3.92 & 4.51 & 4.68 & 4.60 \\
\hline Lafa & 1.78 & 1.65 & 1.72 & 3.47 & 3.97 & 3.72 & 4.47 & 4.45 & 4.46 \\
\hline Utkal Manika & 1.69 & 1.49 & 1.59 & 3.30 & 3.29 & 3.30 & 4.17 & 3.98 & 4.07 \\
\hline $\operatorname{Sem}(+\underline{+}$ & 0.01 & 0.02 & 0.04 & 0.15 & 0.14 & 0.26 & 0.56 & 0.43 & 0.32 \\
\hline C.D.(0.05) & 0.09 & 0.18 & 0.19 & 0.24 & 0.22 & 0.55 & 0.32 & 0.18 & 1.02 \\
\hline \multicolumn{10}{|c|}{ Growing season- Rainy } \\
\hline Maharani & 0.96 & 1.22 & 1.09 & 1.48 & 1.83 & 1.66 & 2.36 & 2.42 & 2.39 \\
\hline Lafa & 1.81 & 1.78 & 1.80 & 2.56 & 2.75 & 2.66 & 2.95 & 3.08 & 3.01 \\
\hline UtkalManika & 0.91 & 0.86 & 0.89 & 1.35 & 1.69 & 1.52 & 1.89 & 1.93 & 1.91 \\
\hline $\operatorname{Sem}(+)$ & 0.33 & 0.13 & 0.15 & 1.14 & 0.23 & 0.31 & 0.22 & 0.34 & 0.23 \\
\hline C.D.(0.05) & 0.53 & 0.36 & 0.55 & 0.39 & 0.52 & 0.13 & 0.45 & 1.05 & 0.10 \\
\hline
\end{tabular}

DAS $=$ Days after sowing 
Table.4 Dry matter accumulation in Pod $\left(\mathrm{g}_{\text {plant }}{ }^{-1}\right)$ of cowpea at 60DAS grown at different growing season of 2012-13 and 2013-14

\begin{tabular}{lcccccc}
\hline Treatment & \multicolumn{3}{c}{ Growing season- summer } & \multicolumn{5}{c}{ Growing season- Rainy } \\
\cline { 2 - 7 } & $2012-13$ & $2013-14$ & Pooled & $2012-13$ & $2013-14$ & Pooled \\
Maharani & 25.95 & 24.56 & 25.26 & 16.65 & 17.65 & 17.15 \\
Lafa & 22.65 & 21.46 & 20.88 & 19.11 & 20.50 & 19.81 \\
Utkalamanika & 20.50 & 19.57 & 18.08 & 15.65 & 16.50 & 16.08 \\
Sem $(+\underline{+})$ & 0.47 & 0.40 & 0.33 & 0.53 & 0.38 & 0.40 \\
\hline C.D. $(0.05)$ & 2.00 & 1.68 & 1.40 & 2.23 & 1.63 & 1.672 \\
\hline
\end{tabular}

DAS= Days after sowing

\section{References}

Abayomi, Y.A., Ajibade, T.V., Samuel, O.F. and Sa'adudeen, B.F. 2008.Growth and yield responses of cowpea (Vignaunguiculata (L.)Walp) genotypes to nitrogen fertilizer (N.P.K.) application in the Southern Guinea Savanna zone of Nigeria. Asian J. Plant Sci., 7(2): 170-176.

Aikins, S.H.M. and Afuakwa, J.J. 2008. Growth and dry matter yield responses of cowpea to different sowing depths. ARPN J. Agri. Biol. Sci., 3(5-6): 50-54.

Blackman, G.E. and Black, G.N. 1968. Physiological and ecological studies in the analysis of plant environment. XII. The role of the light factor in limiting growth. Ann. Bot. (N.S.), 23: 131-145.

Bressani, R. 1985. Nutritive Value of Cowpea. In: Cowpea Research, Production and utilization. Singh, S.R and K.O Rachie (Eds). A Wiley- Inter science Publication: John Wiley and Sons Chischeste Newyork Brisbane Toronto Singapore pp: 353-359.

CRI. 2006. Cowpea Production Guide. Introduction to Cowpea Production. Available online http://www.cropsresearch.org/publicatio ns/pdf/cowpea_Introduction.pdf.

Dadson, R.B., Hashem, F.M., Javaid, I., Joshi, J. and Allen, A.L. 2003. Response of diverse cowpea genotypes to drought.
(CD-ROM) Annual meeting abstracts. ASA, CSSA, SSSA, Madison, WI.

Fatokun, A.C. 2002. Breeding cowpea for resistance to insect pests. Attempted crosses between cowpea and Vignavexillata. In: Challenges and opportunities for enhancing sustainable cowpea production, Fatokun, C.A., S.A. Tarawali, B.B. Singh, P.M.

Haizel, K.A. 1972. The effects of plant density on the growth, development and grain yield of two varieties of cowpeas. Ghana J. Agric. Sci., 5: 163-171.

Kay, D.E. 1979. Food legumes, crop and product digest, No.3.Natural Resources Institute, Chattan, UK.p. 214.

Kvet, J., Ondok, J.P., Necas, J. and Jarvis, P.G. 1971.Methods of Growth Analysis. In: Sestak, Z., Catsky, J. and Jarvis, P.G. (Eds.), Plant Photosynthetic Production: Manual of Methods. Dr W. Junk N.V., The Hague. pp. 343-391.

Langyintuo, A.S., Lowenberg-DeBoer, J., M. Faye, et al. 2003. Cowpea supply and demand in West and Central Africa. Field Crops Res., 82(2-3): 215-231.

Lauriault, L.M. and Kirksey, R.E. 2007.Planting date and furrow-irrigation effects on cowpea for edible dry beans, Southern High Plains, USA. New Mexico State University Res. Report, 757: p. 8.

Mortimore, M.J., B.B. Singh, F. Harris and S.F Blade. 1997. Cowpea in traditional 
cropping system: In Advances in Cowpea Research, Singh, B.B., D.R Mohanraj, D.E Dashiell and L.E.N Jackai (Eds.). Copublication of International Institute of Tropical Agriculture (IITA) and Japan International Research Centre For Agricultural Sciences (JIRCAS): IITA, Ibadan, Nigeria pp.99-113.

Roberts, P.A., Mathews, W.C. Jr. and Ehlers, J.D. 2005. Root-knot nematode resistant cowpea cover crops systems. Agron. J., 97: 1626-1635.

Sanginga, N.K.E., Dashiell, J., Diels, et al.
2003. Sustainable resource management coupled to resilient germplasm to provide new intensive cereal-grainlegume-livestock systems in the dry savanna. Agri. Ecosystems and Environ., 100(2-3): 305-314.

Singh, V. and Singh, B. 1992. Tropical grain legume as important human foods. Economic Bot., 16(46): 310-321.

Turk, K.J., Hall, A.E. and Asbell, C.W. 1980. Drought adaptation of cowpea. I: Influence of drought on seed yield. Agron. J., 72(3): 413-420.

\section{How to cite this article:}

Singh, D.V. and Mukhi, S.K. 2017. Phasic Pattern of Dry Matter Production and Accumulation in Different Parts of Cowpea Cultivars (Vigna unguiculata L. walp.) During Growth and Development Stages under Varied Seasons. Int.J.Curr.Microbiol.App.Sci. 6(4): 347-355. doi: https://doi.org/10.20546/ijcmas.2017.604.038 